\title{
Approach to urological complications early post renal transplant
}

\author{
Akbar Mahmood \\ Nephrology Department, Sultan Qaboos University \\ Hospital, Muscat, Oman
}

This work is licensed under a Creative Commons Attribution 4.0 International License

Received: 2018-08-26

Accepted: 2018-09-30

UDC: 616.1

\section{J CLIN MED KAZ 2018;3(49):24-27}

Corresponding author: Akbar Mahmood, Nephrology Department, Sultan Qaboos University Hospital, Muscat, Oman

Email: drakbar696@hotmail.com

\section{Abstract}

Kidney transplant has been proven treatment of choice for end stage renal disease population due to its benefit of being cost effective and conferring a natural way of way of life despite that fact, that transplantation journey is not devoid of some risks both surgical and medical. Amongst the surgical issues urological problems needs special attention, close surveillance for timely detection and intervention in order to safe guard renal allograft. These complications include lymphocele, seroma, ureteric obstruction and urinary leak. A very simple approach has been suggested to adopt which include concentrating on symptoms and signs, utilizing conventional diagnostic tools followed by appropriate intervention which include not only surgical but medical to curtail infection, adjusting immunosuppression, improving nutrition and mental and physical rehabilitation. This should be kept in mind that time is key to salvage the renal allograft by preserving nephrons. Time means nephrons and large number of nephron mass which has long term morbidity and mortality benefit. Multidisciplinary team based care strategy is mandatory to achieve success.

Key words: lymphocele, seroma, ureteric obstruction and urinary leak

\section{БУЙРЕК ТРАНСПЛАНТАЦИЯСЫНАН КЕЙІНГІ УРОЛОГИЯЛЫК АСКЫНУЛАР \\ Акбар Махмуд \\ Султан Кабустың университеттік ауруханасы, нефрология бөлімі, Маскат, Оман}

\section{ТҰЖЫРЫМДАМА}

Бүйрек трансплантациясы бүйрек жеткіліксіздігінің жантәсілім сатысындағы тұрғындар үшін емдеудің тексерілген және қолайлы әдісі болып табылады, ол экономикалық тиімді және трансплантация процессі хирургиялық, сондай-ақ медициналық тәуекелдерге қарамастан, пациентке әдеттегі өмір салтын ұсынады. Хирургиялық мәселелер арасында урологиялық мәселелер ерекше ықыласты, бүйректік аллотрансплантатын қорғау үшін уақытылы анықтау және араласу үшін жете қадағалауды қажет етеді. Осындай асқынуларға лимфоцеле, серома, несептамырдың обструкциясы және несеп ағуы жатады. Қолдану үшін өте қарапайым әдістеме ұсынылады, ол симптомдар мен белгілерді шоғырлау, инфекцияларды төмендету, иммунодепрессияны түзету, тамақтануды жақсарту және ақыл мен фризикалық жағынан сауықтыру бойынша медициналық шараларды ғана емес, сонымен бірге хирургиялық шараларды енгізетін, ары қарай тиісті араласумен дәстүрлі диагностикалық құралдарды қолдануда. «Уақыт» нефрондарды сүрлеу жолы арқылы бүйректі алло-трансплантты сақтауға кілт екенін еске сақтау қажет. «Уақыт» ол нефрондар саны және нефрондардың салмағы, олар алыстағы ауруға және өлімге әсер етеді. Мультитәртіптік медициналық команданың көмек көрсету стратегиясы кепілдік жетістіктерге ие болады.

Негізгі сөздер: лимфоцелле, серома, несептамырдың обструкциясы, несеп ағуы

\section{УРОЛОГИЧЕСКИЕ ОСЛОЖНЕНИЯ ПОСЛЕ ТРАНСПЛАНТАЦИИ ПОЧКИ}

\section{Акбар Махмуд}

Отделение нефрологии, Университетская больница Султана Кабуса, Маскат, Оман

\section{PEЗЮME}

Трансплантация почки является проверенным и предпочтительным методом лечения для населения с терминальной стадией почечной недостаточности благодаря тому, что является экономически эффективной и предоставляет пациенту привычный образ жизни, несмотря на то, что процесс трансплантации не лишен некоторых рисков, как хирургических, так и медицинских. Среди хирургических вопросов, урологические проблемы требуют особого внимания, тщательного наблюдения для своевременного выявления и вмешательства, чтобы защитить почечный алло-трансплантат. К таким осложнениям относятся лимфоцеле, серома, обструкция мочеточников и подтекание мочи. Для применения предлагается очень простой подход, который заключался в концентрации на симптомах и признаках, использовании традиционных диагностических инструментов, с последующим надлежащим вмешательством, которое включает не только хирургические, но и медицинские мероприятия по снижению инфекции, корректировке иммуноупрессии, улучшению питания и умственной и физической реабилитации. Следует помнить, что «время» является ключом к спасению почечного алло-трансплантата путем консервирования нефронов. «Время» это количество нефронов и массы нефронов, которые влияют на отдаленную заболеваемость и смертность. Стратегия оказания помощи мультидисциплинарной медицинской команды будет иметь гарантированный успех.

Ключевые слова: лимфоцеле, серома, обструкция мочеточников, подтекание мочи 


\section{Introduction}

Renal transplantation is the best modality in patients with end stage renal disease requiring renal replacement therapy both in terms of survival benefits and cost efficiency. Studies have shown that mortality risk of chronic kidney disease who remains on dialysis is four-fold [1] as compare to transplantation with the fact that transplant is three times cheaper as compared to continuing dialysis [2]. This is a proven fact that transplant is the ideal solution with long term beneficial outcomes but it does carry some risks related to the surgical procedure involved. With renal transplant few complications can appear in immediate post-operative period, within days. This usually comprise of surgical wound related issues, ureteric complications involving stricture, obstruction or leakage, vascular problems including renal vein or arterial thrombosis, lymphocele, and bladder leak or outflow obstruction [3]. Streeter and his colleagues have shown that urological complication can risk up to $9 \%$ [4]. Recent data published in 2015 reported this risk to $8 \%[5]$.

Clinical presentation with signs and symptoms usually guides towards a possible etiology. Based on the history and physical findings plausible differentials are rule in and out with the aid of investigative tools. This usually includes routine blood works like blood counts, renal and bone profile, liver functions, urine analysis, imaging like radiographs, ultrasound and CT scan, radioisotope studies. Based on this baseline workup more advance and invasive procedures are planned like pyelograms, ante grade or retrograde with or without cystoscopy. Management is planned according to the problem detected. Morbidity and mortality depends how quickly and efficiently problem has been identified and rectified accordingly. Few are the possible differentials which need to be considered in view to common urological complications encountered early post renal transplant which includes lymphocele, seroma, ureteric obstruction and urinary leak.

\section{Methods}

Extensive literature search has been conducted of the past twenty years targeting urological complications, which occurred during immediate post kidney transplant period. Commonest complications have been outlined along with the most effective management outcomes, evidence-based methods with best outcomes.

\section{Discussion}

We will discuss and highlight salient features of each condition individually and outline a diagnostic approach to establish the exact cause and suggest evidence based management options with particular attention to contain the problem in order to prevent complications perpetuate further. Aim is to salvage the graft and expedite recovery.

\section{Seroma}

It is a collection of serous fluid post operatively which is usually seen in obese patients. This fluid accumulates in the subcutaneous space. Its pathophysiology is poorly understood, diagnosed by ultrasound [6]. Formation of this fluid can be prevented by placing drains which dries out progressively.

\section{Lymphocele}

Peri-nephric retroperitoneal lymphatic fluid collection is called lymphocele. Collection of lymphatic secretions around the graft is a result of secretions from tiny residual lymphatics on the donor kidney around the hilum and iliac vessels which has not been ligated meticulously at the time of allograft implantation. Its incidence is up to $18 \%$. Clinical presentation depends on the site, size and rate of production of lymphocele. Larger collections especially near the hilum can cause bulging of the graft site, obstructive uropathy with renal impairment and symptoms of bladder irritation merits drainage which may continue to drain for months with a risk of infection. Ultrasound Doppler will quantify the amount of fluid any evidence of obstruction and evaluate vasculature supply with flow patterns. CT scan can provide better details which helps in suggesting treatment modality. Small lymphocele may resolve by drainage but conservative management has less than $50 \%$ success rate [7]. Recurrent, persistent and large lymphocele can be managed by prolong drainage, scleroscent agents surgical or laparoscopic marsupialization [8]. Result of fluid analysis in this particular case does not support the diagnosis of lymphocele.

\section{Ureteric obstruction}

Early ureteric obstruction could be the result of peri nephric fluid collection due to back pressure changes. Possible etiological factors are blood clot into ureteric lumen, lymphocele, urinoma and hematoma. Twist in long ureters and stricture or edema at anastomotic site are also well recognized facts. Distal ureter is the commonest site of ureteric stricture [9]. Noninvasive workup quickly evaluates and differentiates between different causes. Ultrasound, radioisotope scans and CT scans are the first and fore most steps which demonstrate pyelocaliectasis. Urgent nephrostomy is required initially till exact location of exact cause with definitive treatment plan. For ureteric strictures besides surgical exploration endo-urological techniques has also been evolved and adopted with favorable outcomes. These include ureterotomy and balloon dilatation which has success rate of $70 \%[10-15]$ and $51 \%$ respectively [16-19].

\section{Urinoma}

This is the extravasation of urine and perinephric fluid collection. Urinary leak has risk of occurrence of $1.5 \%$ amongst overall urological complications with a reported incidence of up to $9 \%[4,5,20]$. It is one of the commonest urological complications with earlier presentation. It results either due to technical issues, ureteric ischemic necrotic injury as a consequence of traumaor devascularization during organ harvesting procedure with leakage at the bladder anastomotic site. Extravasation can result into pelvi-calaceal rupture due to ureteric obstruction. This is a common practice to place DJ stent in the ureter in order to help the anastomosis to heal and prevent obstruction and leakage. Despite this preemptive measure problems can happen and data supports routine use of ureteric stents to minimize these issues [21]. Risk of urinary leakage is only $1 \%$ as compare to $6 \%$ where no stents were deployed post operatively.

\section{Management plan}

As mentioned previously assess patient's condition and local examination of surgical site and obtain a base line workup with $\mathrm{C}$ reactive proteins, septic screen including blood, urine and drain fluid cultures and swabs if any pus discharge from the wound or drain site. Urgent abdominal ultrasound with the Doppler of renal vessels is a cheap and noninvasive first line imaging modality which will help us with information about the perfusion of the renal allograft, size of the fluid collection with any mass affect and provide information about the allograft perfusion and obstruction of the renal tract. Based on this assessment before proceeding further we should commence therapeutic strategy as per patient's condition. If febrile, empirical antibiotics should be started with infectious disease team opinion. Have low threshold for antibiotics as this is the most vulnerable period for developing typical and atypical infections due to the 
reason that patient is heavily immunosuppressed with structural deformity and commonest systems involved are urinary and respiratory tracts $[22,23,24]$. Urinary tract infections may harm the allograft and affects its survival both in short term and long term [25, $26,27]$. Fluid status be optimized either oral or intravenous routes with close monitoring by employing non invasive and invasive tools and placing Foley`s catheter. Bladder cauterization helps to reduce back pressure changes and extravasation of urine especially if the uretrovesical anastomosis is the culprit. If ultrasound shows hydro uretro nephrosis due to sizeable fluid collection intraabdominally then percutaneous ultrasound guided nephrostomy drainage is to place in order to salvage renal allograft from extrinsic compression due to extravasation and rerouting of the urine to minimize chances of sepsis. Percutaneous nephrostogram must be performed to delineate site of injury. Nature of lesion and its extent will guide further to opt the type of corrective measures. Extravasation of the contrast will pin point the injured site and amount of injury. Use of more sophisticated images including renal and bladder scintigrams can be employed over contrast studies which depends on the clinical situations and use DTPA or MAG3 scans which indicates injury by extravasation in case of leak and lack of uptake and a filling defect in case of other conditions like hematoma or seroma. These are non-nephrotoxic studies which help in differential diagnosis. Serial follow up nephrostograms are required to observe healing pattern if conservative management has opted. Conservative approach is adopted usually when leak is distal and small. Close monitoring of clinical condition with renal functions and radiological studies are corner stones to follow up such cases. Clinical and laboratory parameters along with reduction of drain output guide the need to proceed further for surgical intervention [28-32]. Surgical intervention is indicated when there is large urinoma especially with proximal and extensive ureteral injury and non-resolution of leak within 4-6 weeks despite adequate decompression measures and placement of DJ stent with deterioration of clinic biochemical markers. One study has proposed placement of DJ stent post transplant in order to reduce complications of stenosis, urinary leak and help the passage to remain patent [33] another study disproved these benefits claimed [34]. Both the studies has concluded the risk of infection when this stent remain in situ for more than a month $[33,34]$. If extensive injury has been estimated in beginning then it is not wise to wait with conservative approach as it can have serious consequences in terms of sepsis with decrease chances of allograft and patient survival.

This particular patient is a candidate for surgical exploration after initiation of medical management followed by nephrostomy and ante grade stenting as a first step as a bridge to operation

without any delay as extravasation volume is significant. Long ureters has high risk of necrosis with vesico-ureteric junction being the commonest site. Exploration can be done through the same surgical scar. Corrective procedure either ureteric reconstruction or re-implantation is decided on the basis of intraoperative findings of ureteric condition. Ureteroneocystostomy is used for distal ureteric injury near uretro-vesical junction. In case of long segment of ureteric stricture re-implantation of the graft ureter with the native one is considered above the stricture or it can be anastomosed with the renal pelvis to reroute the urine flow by bypassing the defect. Boari flap is used for reconstruction when native ureter is not available for reconstruction. Bladder flap technique is advocated in cases of short ureter and omental interposition is used in uretrocutaneous or vesico cutaneous fistulae after resection. In rare case when patient is not fit for surgery some experts advocate to deploy ureteric stents lifelong with six monthly replacement policy.

\section{Conclusion}

Three types of complications can occur in immediate post renal transplant. Vascular, urological and wound related. Modern investigative tools must be employed which will aid definitive diagnosis among vast list of differentials and proceed accordingly. Any surgical issues in renal allograft recipients should be taken seriously and addressed promptly as these may result into graft loss [35].

Investigative workup should be initiated immediately without any delay in medical management as well. These are immunosuppressed population and serious complications appear readily. Role of endo urologist is an added advantage if available through which morbidity of open surgeries can be minimized with optimum results. Take home messages include multidisciplinary care approach should be opted by transplant surgeon, urologist, nephrologist, interventional radiologist and infectious disease consultant. Infection risk must be preempted from the beginning and antibiotics should be the integral part of the management plan, medication should be adjusted according to the creatinine clearance. There should be a low threshold for surgical intervention and exploration. Wound care, nutritional support and psycho social support will expedite the recovery. Adhering to above mentioned principles will help in smoother and speedy recovery, lesser hospital stay with significantly lower health care cost.

Conflict of Interest: There is no conflict of interest to declare. Funding: There is no funding to declare.

Ethical Approval: No ethical approval is required for review articles.

\section{References}

1. McDonald SP, Craig JC, Australian and New Zealand Paediatric Nephrology Association. Long-term survival of children with end-stage renal disease. N Engl J Med 2004; 350:2654.

2. National Kidney and Urologic Diseases Information Clearing house. Kidney disease statistics for the United States. National Institutes of Health; 2012. Publication No. 12e3895.

3. Routh JC, Yu RN, Kozinn SI, et al. Urological complications and vesicoureteral reflux following pediatric kidney transplantation. J Urol 2013; 189:1071.

4. Streeter EH, Little DM, Cranston DW, Morris PJ. The urological complications of renal transplantation: a series of 1535 patients. BJU Int 2002;90:627e34.

5. Lempinen J, Stenman J, Kyllonen L, Salmela K. Surgical complications following 1670 consecutive adult renal transplantations: a single center study. Scand J Surg 2015

6. O’Neill CW. Ultrasonography in renal transplantation. Am J Kidney Dis. 2002;39:663-678.

7. Bailey SH, Mone MC, Holman JM, Nelson W. Laparoscopic treatment of postrenal transplant lymphoceles. SurgEndosc 2003;17:1896e9

8. Kolonko RKA, Chudek J, Ziaja J, Pawlicki J, Maly A, Kunsdorf- Wnuk A, et al. Did volume of lymphocele after kidney 
transplantation determine the choice of treatment modality? Transplant Proc 2007;39:2740e3.

9. Kumar S, Ameli-Renani S, Hakim A, Jeon JH, Shrivastava S, Patel U. Ureteral obstruction following renal transplantation: causes, diagnosis and management. Br J Radiol 2014;87.20140169.

10. Bhayani SB, Landman J, Slotoroff C, Figenshau RS. Transplant ureter stricture: Acuciseendoureterotomy and balloon dilation are effective. $J$ Endourol 2003;17:19e22.

11. El-Nahas AR. Retrograde endopyelotomy: a comparison between laser and Acucise balloon cutting catheter. CurrUrol Rep 2007;8:122e7.

12. Katz R, Pode D, Gofrit ON, Shenfeld OZ, Landau EH, Golijanin D, et al. Transurethral incision of Ureteroneocystostomy strictures in kidney transplant recipients. BJU Int 2003;92:769e71.

13. Kristo B, Phelan MW, Gritsch HA, Schulam PG. Treatment of renal transplant ureterovesical anastomotic strictures using ante grade balloon dilation with or without holmium:YAG laser endoureterotomy. Urology 2003;62:831e4

14. He Z, Li X, Chen L, Zeng G, Yuan J, Chen W, et al. Endoscopic incision for obstruction of vesico-ureteric anastomosis in transplanted kidneys. BJU Int 2008;102:102e6.

15. Gdor Y, Gabr AH, Faerber GJ, Wolf Jr JS. Holmium: yttriumaluminum-garnet laser endoureterotomy for the treatment of transplant kidney ureteral strictures. Transplantation 2008; 85:1318e21

16. Bachar GN, Mor E, Bartal G, Atar E, Goldberg N, Belenky A. Percutaneous balloon dilation for the treatment of early and late ureteral strictures after renal transplantation: long-term follow-up. CardiovascInterventRadiol 2004;27: 335e8.

17. Bromwich E, Coles S, Atchley J, Fairley I, Brown JL, Keoghane SR. A 4-year review of balloon dilation of ureteral strictures in renal allografts. J Endourol 2006;20: 1060e1.

18. Aytekin C, Boyvat F, Harman A, Ozyer U, Colak T, Haberal M. Percutaneous therapy of ureteral obstructions and leak after renal transplantation: long-term results. CardiovascIntervent Radiol 2007;30:1178e84.

19. Juaneda B, Alcaraz A, Bujons A, Guirado L, Diaz JM, Marti J, et al. Endourological management is better in early-onset ureteral stenosis in kidney transplantation. Transplant Proc 2005;37:3825e7

20. Nie ZL, Zhang KQ, Li QS, Jin FS, Zhu FQ, Huo WQ. Treatment of urinary fistula after kidney transplantation. Transplant Proc 2009;41:1624e6.

21. Benoit G, Blanchet P, Eschwege P, Alexandre L, Bensadoun H, Charpentier B. Insertion of a double pigtail ureteral stent for the prevention of urological complications in renal transplantation: a prospective randomized study. J Urol 1996;156: 881e4

22. Dharnidharka VR, Stablein DM, Harmon WE. Post-transplant infections now exceed acute rejection as cause for hospitalization: a report of the NAPRTCS. Am J Transplant 2004; 4:384.

23. Hogan J, Pietrement C, Sellier-Leclerc AL, et al. Infection-related hospitalizations after kidney transplantation in children: incidence, risk factors, and cost. Pediatr Nephrol 2017; 32:2331.

24. Puliyanda DP, Stablein DM, Dharnidharka VR. Younger age and antibody induction increase the risk for infection in pediatric renal transplantation: a NAPRTCS report. Am J Transplant 2007; 7:662.

25. Silva A, Rodig N, Passerotti CP, et al. Risk factors for urinary tract infection after renal transplantation and its impact on graft function in children and young adults. $J$ Urol 2010; 184:1462.

26. Dharnidharka VR, Agodoa LY, Abbott KC. Effects of urinary tract infection on outcomes after renal transplantation in children. Clin J Am Soc Nephrol 2007; 2:100.

27. Esezobor CI, Nourse P, Gajjar P. Urinary tract infection following kidney transplantation: frequency, risk factors and graft function. Pediatr Nephrol 2012; 27:651.

28. Matalon TA, Thompson MJ, Patel SK, Ramos MV, Jensik SC, Merkel FK. Percutaneous treatment of urine leaks in renal transplantation patients. Radiology 1990;174 (3 Pt 2) :1049e51.

29. Campbell SC, Streem SB, Zelch M, Hodge E, Novick AC. Percutaneous management of transplant ureteral fistulas: patient selection and long-term results. J Urol 1993;150: 1115e7.

30. Swierzewski SJ, Konnak JW, Ellis JH. Treatment of renal transplant ureteral complications by per cutaneous technique. J Urol 1993;149:986e7.

31. Bhagat VJ, Gordon RL, Osorio RW, LaBerge JM, KerlanJr RK, Melzer JS, et al. Ureteral obstructions and leaks after renal transplantation: outcome of percutaneous antegrade ureteral stent placement in 44 patients. Radiology 1998;209:159e67.

32. Alcaraz A, Bujons A, Pascual X, Juaneda B, Marti J, de la Torre P, et al. Percutaneous management of transplant ureteral fistulae is feasible in selected cases. Transplant Proc2005;37:2111e4.

33. Tavakoli A, Surange RS, Pearson RC, et al. Impact of stents on urological complications and health care expenditure in renal transplant recipients: results of a prospective, randomized clinical trial. J Urol 2007; 177:2260.

34. Dharnidharka VR, Araya CE, Wadsworth CS, et al. Assessing the value of ureteral stent placement in pediatric kidney transplant recipients. Transplantation 2008; 85:986.

35. Irtan S, Maisin A, Baudouin V, et al. Renal transplantation in children: critical analysis of age related surgical complications. Pediatric Transplant 2010; 14:512.

How to cite this article: Akbar Mahmood. Approach to urological complications early post renal transplant. J Clin Med Kaz. 2018; 3(49):24-27 